DOI https://doi.org/10.36059/978-966-397-159-9/109-127

\title{
CERTAIN ASPECTS OF UKRAINIAN BORDER SECURITY MECHANISM FUNCTIONING
}

\section{Pavlo Volynets}

\section{INTRODUCTION}

The issue of effective national security protection of Ukraine arises particularly acute, especially in the border sphere under the conditions of a hybrid war pursuance in the east of Ukraine.

The protection of national sovereignty and territorial integrity of Ukraine, ensuring its economic and information security as the most important functions of the state, the matter of the entire Ukrainian people in accordance with Article 17 of the Constitution of Ukraine are determined as main tasks of national security ${ }^{1}$. Thus, the legislator clearly defines the importance of the function to ensure the security of a man, society and the state and Article 17, Paragraph 3 of the Constitution of Ukraine states that the state security provision and protection of the state border of Ukraine are entrusted with the respective military formations and law enforcement bodies of the state, the organization and rules of procedure of which are determined by the law ${ }^{2}$. From the above provisions of the highest law of Ukraine, it follows that the security of the state border is an integral component of the existence of Ukraine's national security as a state. Therefore, the security of the state border is one of the most important functions of the state.

It should be noted that the issues of national security protection of Ukraine are widely covered in scientific and specialized literature. In recent years, there has been a sharp increase in scientific publications on the subject given the actual hybrid war Ukraine happened to find itself in 2014.

\footnotetext{
${ }^{1}$ Konstytutsiia Ukrainy: Zakon Ukrainy vid 28.06.1996 № 254k/96-VR. Data onovlennia: 30.09.2016. URL: http://zakon3.rada.gov.ua/laws/main/254k/96-vr. (data zvernennia 23.05.2019 roku).

${ }^{2}$ Konstytutsiia Ukrainy: Zakon Ukrainy vid 28.06.1996 № 254k/96-VR. Data onovlennia: 30.09.2016. URL: http://zakon3.rada.gov.ua/laws/main/254k/96-vr. (data zvernennia 23.05.2019 roku).
} 
Thus, the issue of state administration in the field of national security of Ukraine was studied by Sytnyk H. P., ${ }^{3}$ Tsevelov O. Ye., Zhuk S. M. ${ }^{4}$ studied topical issues of ensuring border security of Ukraine within the national security system.

A. F. Melnyk paid attention to the regularities and peculiarities of the state mechanisms functioning within the system of national security of Ukraine $^{5}$. The issue of the border security mechanisms functioning in the context of the theory of integrated border management was studied by Lytvyn M. M. ${ }^{6}$

Kuprienko D. A. studied the role of the State Border Guard Service of Ukraine within the state mechanism of border security, as well as the problems of forming a categorical and conceptual apparatus for border security $^{7}$. The issue of decomposition of threats and dangers to the national security of the state in the border sphere was studied by Babii Yu.

However, the role and place, as well as the peculiarities of the operational and search component of the state mechanism of ensuring the border security of Ukraine in the conditions of its active formation and transformation, remain unclear.

The purpose of our research is to study the individual aspects of the functioning of the mechanism for ensuring border security, justify the role and place of the operational and investigative component in it, taking into account the determination of views upon the role and place of the State Border Service of Ukraine in it.

The following methods have been used in the process of the research to achieve the purpose and to solve scientific problems: systematic analysis, analogy, comparison in the process of undertaking analysis of scientific and specialized literature, as well as legislative instruments on national security

${ }^{3}$ Sytnyk G. P. (2012) Derzhavne upravlinnja u sferi nacionaljnoji bezpeky (konceptualjni ta orghanizacijno-pravovi zasady) [Public administration in the field of national security (conceptual and organizational and legal bases)]. Kyiv : NADU. (in Ukrainian).

${ }^{4}$ Tsevelov O. Ye., Zhuk S. M. (2017) Aktualni pytannia zabezpechennia prykordonnoi bezpeky Ukrainy u systemi natsionalnoi bezpeky [Topical issues of ensuring the border security of Ukraine in the national security system].Investments : practice and experience, no10,pp.8890. (in Ukrainian).

5 Melnyk A.F., Obolenskyi Yu.A., Vasyna A.Yu. (2014) Derzhavne upravlinnia [Governance] / A.F. Melnyk (ed). Kyiv : Znannia. (in Ukrainian).

6 Lytvyn M. M. (2012) Intehrovane upravlinnia kordonamy [Integrated border management]. Khmelnytsky : NADPSU. (in Ukrainian).

7 Kuprijenko D. A. (2014) Osnovni ponjattja ta kateghoriji u sferi zabezpechennja prykordonnoji bezpeky [Basic concepts and categories in the field of border security].Collection of scientific papers of the National Academy of the State Border Guard Service of Ukraine. Series: Military and Technical Sciences, no. 1(64), pp. 357-368.(in Ukrainian). 
and operational and investigative activity, identification of generalization and data structuring to determine the main, generalized functions of the national mechanism of ensuring the border security of Ukraine, the synthesis of individual functions of operational and search activity actors in order to determine their place and role within system of the national mechanism of ensuring the border security of Ukraine.

\section{Justification of the content of the concept of border security mechanism}

The complexity of the concept definition of the mechanism of border security of Ukraine ensuring is stipulated by: first, significant content and functional load of its components; secondly, the lack of a well-established conceptual apparatus, which defines the peculiarities of different types of activities in the sphere of border security of Ukraine, the difficulties associated with ensuring the effective joint activity of different actors, etc.

According to the explanatory dictionary of the Ukrainian language, the mechanism is an internal structure, the system of something ${ }^{8}$. Usually, the term mechanism includes not only the components of the internal component of anything, but also describes the principles and order of their interaction with each other and with the external environment. Melnyk A. F., in the context of studying the laws of functioning of state-power mechanisms, in particular notes that state administration is one of the types of activity for the exercise of state power (along with law-making and justice), which consists in the practical implementation of organizational, executive and administrative functions in order to enforce the requirements of the legislation and to exercise managerial influence over certain objects thereupon ${ }^{9}$.

According to Morchenko M. N. one should understand the term of "State mechanism" as the system of different state bodies, organizations, materiel resources of state power and management, the armed forces ${ }^{10}$. Thus, A. P. Prytula defines the constituent mechanism of the state as the so-called material appendage, which includes the police, penitentiary institutions,

${ }^{8}$ Slovnyk ukrajinsjkoji movy: Akademichnyj tlumachnyj slovnyk ukrajinsjkoji movy [Dictionary of the Ukrainian Language: Academic Interpretative Dictionary of the Ukrainian Language].Retrieved from:https://sim.in.ua.mekanizm (accessed21 May 2019). (in Ukrainian).

9 Melnyk A.F., Obolenskyi Yu.A., Vasyna A.Yu. (2014) Derzhavne upravlinnia [Governance] / A.F. Melnyk (ed). Kyiv : Znannia. (in Ukrainian).

${ }^{10}$ Marchenko M.N. (2014). Teoriya gosudarstva i prava[Theory of government and rights]/ V. K. Babaeva (ed.). Moskva : Yurayt. (in Russian).. 
security agencies, the armed forces and other law enforcement agencies of the state ${ }^{11}$.

Also, Melnyk A. F. notes that the role of the state power in the course of the elaboration of the state-administrative mechanisms is conditioned by its functions within the system of state administration, and by the extent to which they ensure the implementation of the functions of the management system $^{12}$.

Thus, in the general perception one can qualify the state mechanisms as the systems of state authorities and local self-government bodies, which, with the help of certain tools, realize the influence (interference) upon certain spheres of life in order to achieve the goals of state policy within certain spheres of life of society and the state.

When it comes to social mechanisms it is necessary to clearly define the following main components of it, namely: the purpose of mechanisms (to solve what tasks they are aimed at); the internal structure of the mechanism (which consists of certain actors that perform the tasks of the mechanism alone or in interaction); the actors of the mechanism (elements of its internal construction, as well as the main driving forces in solving problems); the role and place of the mechanism within the social system (the relative weight of the mechanism in solving specific social problems, as well as the peculiarities of its interaction with the environment); functions of the (set of specific tools used in accordance with certain procedures), etc.

Considering the above, the state security mechanism is a system of state authorities and local self-government bodies that, through certain tools, realize the influence (interference) into the sphere of state security in order to eliminate threats.

Sytnyk H. P. studying the issue of forming and assessing the effectiveness of security mechanisms determines that they should be considered in two aspects:

- ontological, when the basis for the conclusions on the foundations of this mechanism consists in the objective properties and qualities of materia that exist regardless of human consciousness;

11 Prytula A.M. (2019) Taktyko-pravovi zasady operatyvno-sluzhbovoi diialnosti Derzhavnoi prykordonnoi sluzhby Ukrainy : monohrafiia [Tactical and legal principles of the operational service of the State border service of Ukraine : monograph]. Odesa : Feniks. (in Ukrainian)..

12 Melnyk A.F., Obolenskyi Yu.A., Vasyna A.Yu. (2014) Derzhavne upravlinnia [Governance] / A.F. Melnyk (ed). Kyiv : Znannia. (in Ukrainian). 
- epistemological, when the basis of these conclusions consists in the generally accepted truths (laws), established by human beings at this stage of science development and formed on this basis their subjective assessments ${ }^{13}$.

It is important to identify the most important elements of the content of the concept of national security. Thus, according to the Law of Ukraine "On National Security", the national security of Ukraine is determined as the protection of state sovereignty, territorial integrity, democratic constitutional order and other national interests of Ukraine against real and potential threats ${ }^{14}$.

Therefore, the national security system should provide for effective protection against various types of threats. According to the new explanatory dictionary of the Ukrainian language, the term "Type" is defined as a separate field of work, occupancy, variety in a number of subjects, phenomena, etc. as well as a subsection that integrates a number of subjects, phenomena on common grounds and is part of the general higher section ${ }^{15}$.

On the basis of the analysis of the legislation, as well as the scientific and specialized literature devoted to the problem of national security, it is possible to determine the national-level security structure of Ukraine by its types (proposed in Figure 1).

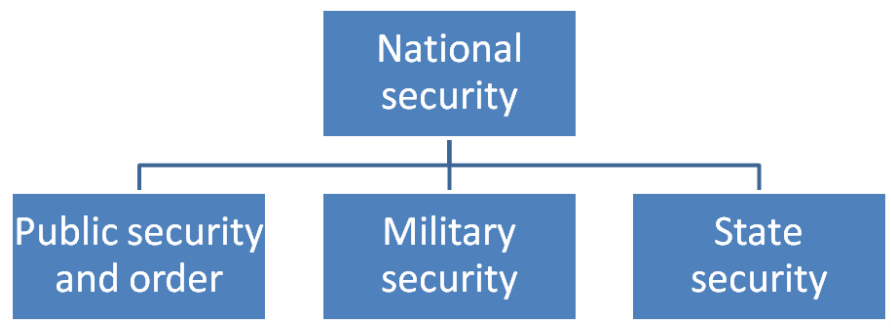

Fig. 1. Types of security

\footnotetext{
${ }^{13}$ Sytnyk G. P. (2012) Derzhavne upravlinnja u sferi nacionaljnoji bezpeky (konceptualjni ta orghanizacijno-pravovi zasady) [Public administration in the field of national security (conceptual and organizational and legal bases)]. Kyiv : NADU. (in Ukrainian).

${ }^{14}$ Pro natsionalnu bezpeku Ukrainy: Zakon Ukrainy vid 21.06.2018 Vidomosti Verkhovnoi Rady (VVR), 2018, № 31, st.241 URL: https://zakon.rada.gov.ua/laws/show/2469-19 (data zvernennia 18.06.2019 roku).

${ }^{15}$ Novyi tlumachnyi slovnyk ukrainskoi movy u trokh tomakh (2008) [A new interpretative dictionary of the Ukrainian language in three volumes]. Kyiv: Akonit.Vol. 1. P. 202. (in Ukrainian).
} 
Article 1 of the Law of Ukraine "On National Security" defines the terms: national security, military security, state security, as well as public security and order. In such a manner, according to the definitions of the law:

military security is the protection of state sovereignty, territorial integrity and democratic constitutional order and other vital national interests against military threats;

state security is the protection of state sovereignty, territorial integrity and democratic constitutional order and other vital national interests against real and potential threats of a non-military nature;

public security and order is the protection of vital for the society and the person interests, rights and freedoms of the individual and the citizen, insurance of which is the priority task in the activity of the security forces, other state authorities, local self-government bodies, their officials and the public, who carry out concerted efforts for implementation and protection of national interests from the effect of threats ${ }^{16}$.

The results of studies of national security problems by national scientists convincingly show that the security structure shown in Figure 1 is not exhaustive, since it covers the issue of protection of the basic vital interests of the individual, society and the state only against common types of threats. However, the multifaceted nature of life, and as a result of the variety of threats and challenges (which in turn are constantly transformed), require the identification of other special types of national security.

Consequently, the national legislation provides other formulations of types of security. According to the law of Ukraine "On National Police", ensuring public security is one of the areas of activity of the national police of Ukraine ${ }^{17}$. However, the law does not provide a clear definition of these definitions, which forms different scientific approaches to understanding the content of public security, which significantly expands the scientific views on the topic.

In such a manner, Panova O. O. believes that "in the broad sense, public security is a set of social relations regulated by the body of norms (both legal and customary) that influence an indefinite circle of persons in order to create an atmosphere of inward peace, security, trust. In its narrow sense,

\footnotetext{
${ }^{16}$ Pro natsionalnu bezpeku Ukrainy: Zakon Ukrainy vid 21.06.2018 Vidomosti Verkhovnoi Rady (VVR), 2018, № 31, st.241 URL: https://zakon.rada.gov.ua/laws/show/2469-19 (data zvernennia 18.06.2019 roku).

${ }^{17}$ Pro Natsionalnu politsiiu Ukrainy: Zakon Ukrainy vid 02.07.2015 № 580-VIII. Data onovlennia: 06.02.2018. URL: http://zakon5.rada.gov.ua/laws/show/580-19. (data zvernennia 10.02.2019 roku).
} 
public security is a set of social relations regulated by the legal propositions aimed at preventing threats to the population ${ }^{18}$.

Abroskin V. V. considering the term "public security" in general, thinks that "public security should be understood as legally regulated public relations, within which authorized by the state bodies and persons carry out activities aimed at preventing and termination of unlawful encroachments, natural and man-made emergencies, minimizing their negative consequences in order to maintain the state of protection of the rights, freedoms and interests of individuals and legal entities, society and the state." He also believes that this definition should be legally enshrined in the national legal boundaries ${ }^{19}$.

Going part way with the author, we believe that according to the author's definition of the content of public security, it covers certain vital areas of public life, and therefore, in its content, represents a certain area of national security.

A sphere is a set of conditions, an environment in which something happens; the area of physical or spiritual life, human or social activity ${ }^{20}$.

In our opinion, the sphere of national security include: border security, environmental security, ethno-political security, international security, cyber security, economic security, information security, etc.

Spheres of national security are presented in the figure (Fig. 2).

It should be noted that the list of national security spheres is not exhaustive, as threats have a tendency to transform. The constant transformation of views upon the substantive content of the national security system takes place against the backdrop of real and potential threats analysis. Therewith, the threat is considered as the possibility or inevitability of the emergence of something dangerous, annoying ${ }^{21}$, in other words, the potential risk of some harm.

${ }^{18}$ Panova O.O. (2017) Informatsiine zabezpechennia publichnoi bezpeky v Ukraini [Public security information in Ukraine]. Actual problems of domestic jurisprudence, vol. 2, no.6,p.126.

${ }_{19}$ Abroskyn V.V. (2019) Administratyvno-pravovi zasady zabezpechennia Natsionalnoiu politsiieiu Ukrainy publichnoi bezpeky $\mathrm{v}$ umovakh antyterorystychnoi operatsii : monohrafiia [Administrative and legal principles of ensuring public security in the conditions of anti-terrorist operation by the national police of ukraine: monograph]. Kharkiv: Folio. (in Ukrainian).

${ }^{20}$ Novyi tlumachnyi slovnyk ukrainskoi movy u trokh tomakh (2008) [A new interpretative dictionary of the Ukrainian language in three volumes]. Kyiv : Akonit.Vol. 3.P.489. (in Ukrainian).

${ }^{21}$ Novyi tlumachnyi slovnyk ukrainskoi movy u trokh tomakh (2008) [A new interpretative dictionary of the Ukrainian language in three volumes]. Kyiv: Akonit.Vol. 1. P. 202. (in Ukrainian).. 


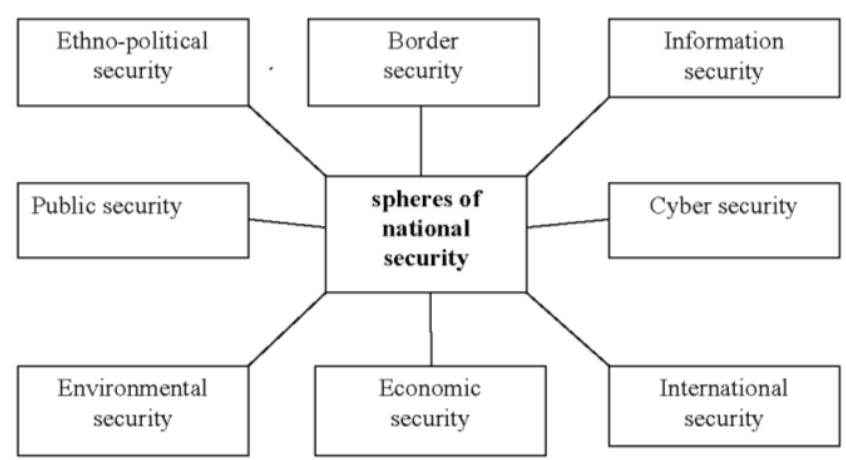

Fig. 2 Spheres of national security

Since 2014, after the Crimea annexation by the Russian Federation and the unleashing of the so-called hybrid war in the east of Ukraine, the process of radical reconsideration of the place and the importance of effective counteraction to the threats to the national security system of Ukraine has begun. According to the analytical report of the National Institute for Strategic Studies since the beginning of large-scale aggression by the Russian Federation, it has become apparent that the current form of the national security system is not able to perform its functions effectively. The country is now facing with extremely complex challenges, as it must carry out a comprehensive reform of the national security system and effectively overcome corruption in a short time, with significantly limited means, while at the same time providing for protection of fundamental national values such as independence, territorial integrity, state sovereignty, protection of rights and human freedoms, the rule of law, prosperity, peace and security ${ }^{22}$.

Different scientists and scientific schools use various basic concepts in the process of defining the spheres of national security. So, Vlasiuk O. S. distinguishes the following areas of national security: political, economic, socio-demographic, military, religious relations, information ${ }^{23}$.

Considering the concept of national security in the border sphere as border security Lytvyn M. M. defines that border security is a specific type

22 Conceptual frame work for development of the National security system of Ukraine(2015) Analytical report the National Institute for Strategic Studies.KyivRetrieved from:http://en.niss.gov.ua/public/File/docs/national_security_final.pdf.

${ }^{23}$ Vlasiuk O. S. (2016) Natsionalna bezpeka Ukrainy: evoliutsiia problem vnutrishnoi polityky [National security of Ukraine: the evolution of domestic policy issues]. Kyiv : NISD. (in Ukrainian).. 
of national security, which is defined as the state of protection of vital interests of the individual, society and the state in the border sphere ${ }^{24}$.

According to Kuprienko D. A., border security is a component of national security that has internal and external dimensions, which gives reason to speak about its systemic character. Considering this, the concept of "border security ensuring" should be understood as a systematic activity of state bodies, public institutions and individual citizens, aimed at the reliable protection of the national interests of the country from external and internal threats that appear in the border sphere and their effective counteraction ${ }^{25}$.

Scientists Tsevelov O. Ye. and Zhuk S. M., among other things, state that border security should include the following elements: scientific theory, conceptual foundation, policy, strategy and tactics, a complex of state and public institutions and organizations providing border security, and facilities for its ensuring ${ }^{26}$.

Shchokiv V. H. studying the specified range of problems in the context of national security management determines that national security management should form an optimal system of state-political institutions with effective coordination and distribution of functions of government agencies ${ }^{27}$.

The actors of the national security mechanism are certain military formations and law enforcement agencies reduced to the security and defence sector.

According to Article 12 of the Law of Ukraine "On National Security" the security and defence sector includes: Ministry of Defence of Ukraine, Armed Forces of Ukraine, State Special Service of Transport, Ministry of Internal Affairs of Ukraine, National Guard of Ukraine, National Police of Ukraine, State Border Guard Service of Ukraine, State Migration Service of Ukraine, State Emergency Service of Ukraine, Security Service of Ukraine, State Guard Service of Ukraine, State Service for Special Communication and Information Protection of Ukraine, the apparatus of the National

24 Lytvyn M. M. (2012) Intehrovane upravlinnia kordonamy [Integrated border management]. Khmelnytsky : NADPSU. (in Ukrainian).. 416p. p.14.

${ }^{25}$ Kuprijenko D. A. (2014) Osnovni ponjattja ta kateghoriji u sferi zabezpechennja prykordonnoji bezpeky [Basic concepts and categories in the field of border security]. Collection of scientific papers of the National Academy of the State Border Guard Service of Ukraine. Series: Military and Technical Sciences, no. 1(64), pp. 357-368.(in Ukrainian).

${ }^{26}$ Tsevelov O. Ye., Zhuk S. M. (2017) Aktualni pytannia zabezpechennia prykordonnoi bezpeky Ukrainy u systemi natsionalnoi bezpeky [Topical issues of ensuring the border security of Ukraine in the national security system].Investments : practice and experience, no10,pp.8890. (in Ukrainian).

${ }^{27}$ Shchokin H. V., Holovatyi M. F., Antoniuk O. V., Sladkevych V. P. (ed.)(2007) Menedzhment [Management]. Kyiv : MAUP. (in Ukrainian).. 
Security and Defence Council of Ukraine, the intelligence agencies of Ukraine, the central executive authority that provides for the formation and implementation of the state military-industrial policy ${ }^{28}$.

However, functionally, the security ensuring mechanism should take into account the ability to involve in the implementation of its own functions additional actors that may be involved on a temporary, periodic or episodic basis. Therefore, the law also states that "Other state authorities and local government bodies carry out their national security functions in cooperation with the bodies belonging to the security and defence sector" 29 .

Thus, the legislator determines that the security and defence sector of Ukraine consists of four interconnected components: security forces; defence forces; defence-industrial complex; citizens and civic associations voluntarily involved in national security ${ }^{30}$.

On the basis of the foregoing, it is possible to identify mechanisms for ensuring the border security of Ukraine as an activity of government agencies and local self-government bodies, military formations and law enforcement agencies, which, together with the involvement of the industrial and economic complex, as well as the entire Ukrainian people, implements a system of measures to protect the interests of the individual, society and the states within the border sphere.

At the same time, the border sphere is defined as a specific branch of international and internal public relations, concerning the issues of contractual legal formulation of the state border, maintaining legal relations in it, as well as a special area of activity of the actors of state administration concerning the border policy implementation ${ }^{31}$.

The main actors of the national-level border security mechanism are the Ministry of Internal Affairs of Ukraine, which ensures the formation and implementation of state policy in the field of protection of the state border of

\footnotetext{
${ }^{28}$ Pro natsionalnu bezpeku Ukrainy: Zakon Ukrainy vid 21.06.2018 Vidomosti Verkhovnoi Rady (VVR), 2018, № 31, st.241 URL: https://zakon.rada.gov.ua/laws/show/2469-19 (data zvernennia 18.06.2019 roku).

${ }^{29}$ Pro natsionalnu bezpeku Ukrainy: Zakon Ukrainy vid 21.06.2018 Vidomosti Verkhovnoi Rady (VVR), 2018, № 31, st.241 URL: https://zakon.rada.gov.ua/laws/show/2469-19 (data zvernennia 18.06.2019 roku).

${ }^{30}$ Pro natsionalnu bezpeku Ukrainy: Zakon Ukrainy vid 21.06.2018 Vidomosti Verkhovnoi Rady (VVR), 2018, № 31, st.241 URL: https://zakon.rada.gov.ua/laws/show/2469-19 (data zvernennia 18.06.2019 roku).

31 Lytvyn M. M. (2012) Intehrovane upravlinnia kordonamy [Integrated border management]. Khmelnytsky : NADPSU. (in Ukrainian). 416p.
} 
Ukraine and protection of Ukraine's sovereign rights in its exclusive (maritime) economic zone ${ }^{32}$.

The State Border Service of Ukraine directly implements the state policy within the security sphere of the state border of Ukraine and protection of the sovereign rights of Ukraine in its exclusive (maritime) economic zone.

However, effectiveness in the resolution of issues concerning border security ensuring by Ukraine is achieved through the independent and joint as well as coordinated efforts of the Ukrainian security and defence forces acting in the performance of their assigned tasks. However, given the extreme diversification of the spheres of activity of these actors, there are a number of problems in ensuring the effective management of the border security mechanism. The controller of the working efficiency of the state border security mechanism is its ability to respond adequately and in a timely manner to emerging threats.

\section{Threats as a factor of impact upon the state mechanism of border security of Ukraine}

Lytvyn M. M. noted that the establishment and functioning of the border security system is based on certain laws. First of all, it depends upon its construction, the nature of the threats, and efficiency and legal capability depends upon the economic potential of the state. The real perception and analysis of threats and risks, their proper classification and assessment is a compulsory condition therewith ${ }^{33}$.

As a result of intensification of various contradictions, both internal and external threats are created, the rise of which is given by foreign states (groups of states), individual social groups, citizens, processes and phenomena in different spheres of human life and activities, societies and states $^{34}$.

Border security threats can be identified in some way by examining the tasks performed by the State Border Guard Service of Ukraine within the system of integrated border management in cooperation with other national and foreign agencies and organizations. Among these tasks are: legal and

\footnotetext{
${ }^{32}$ Pro natsionalnu bezpeku Ukrainy: Zakon Ukrainy vid 21.06.2018 Vidomosti Verkhovnoi Rady (VVR), 2018, № 31, st.241 URL: https://zakon.rada.gov.ua/laws/show/2469-19 (data zvernennia 18.06.2019 roku).

${ }^{33}$ Lytvyn M.M. Aktualni pytannia zabezpechennia prykordonnoi bezpeky Ukrainy v suchasnykh umovakh derzhavotvorennia [Topical issues of ensuring the border security of Ukraine in modern conditions of state formation] Retrieved from:https://dpsu.gov.ua > upload > file > golova_11(accessed 10 Octover 2019). (in Ukrainian).

${ }^{34}$ Horbulin V.P., Kachynskyi A.B. (2009) Zasady natsionalnoi bezpeky Ukrainy[National security principles of Ukraine]. Kyiv : Intertekhnolohiia.P. 136. (in Ukrainian).
} 
regulatory framework in the field of integrated border management; ensuring cooperation in combating cross-border and transnational crime; control of the entry and stay of foreigners and stateless persons in Ukraine in accordance with European standards; information management and risk analysis; implementation of European standards for border, customs and other controls; facilitation of international economic activity and development of international trade, improvement of the state transit capacity; improving the customs administration system and improving the quality of customs regulation ${ }^{35}$.

Thus, Babii Yu. A., studying the threats to the national security of the state in the border sphere, defines the following ones: the spread of corruption, bribery; infringement of inviolability of the state border and the territorial integrity of the country; existing and potential territorial requirements on the part of foreign states; incompleteness of the contractual legal registration of the state border; ethnic autonomization of certain regions of Ukraine; inadequacy of the capabilities of the border control authorities, the nature and extent of the threats ${ }^{36}$.

Considering the international experience on these issues, it is necessary to note the separate opinions of public associations of human rights agencies i.e. according to experts of the Brennan Justice Centre in New York, one of the main threats to national security is the concealment of information from the public, as well as the presence of secret regulatory and legal framework in the state. In their opinion, systematic secrecy in dealing with national security issues undermines the foundations of democratic self-government ${ }^{37}$.

These and other scientific studies and socio-political views on national security issues clearly indicate the potential for an extraordinary diversity of threats to Ukraine's border security. For the sake of convenience, as well as the simplification of their understanding in the sense of the danger, all threats were structured according to the spheres of public life.

As a result of structuring, the following groups of threats to Ukraine's border security were identified:

1) Threats to life, health, dignity, property of citizens;

2) Threats aimed at attempting to violate the territorial integrity of Ukraine and the inviolability of the state border of Ukraine;

35 Lytvyn M. M. (2012) Intehrovane upravlinnia kordonamy [Integrated border management]. Khmelnytsky : NADPSU. (in Ukrainian). 416p. p.14.

${ }^{36}$ Babii Yu. (2016) Udoskonalennia dekompozytsii zahroz i nebezpek natsionalnii bezpetsi derzhavy u prykordonnii sferi [Improvement of decomposition of threats and dangers to the national security of the state in the border area]. Proceedings of the National Academy of State Border Guard Service of Ukraine. Series: military and technical sciences, no. 4, pp. 185-196. Khmelnytskyi. (in Ukrainian).

37 Transparency\&Oversight/Brenan Center for Justiceat NYU low.Retrieved from: https://www.brennancenter.org/issues/protect-liberty-security/transparency-oversight BB. 
3) Threats related to intelligence and subversive activity of special services of foreign states and organizations;

4) Threats related to cross-border crime;

5) Threats related to violations of the order of crossing the state border of Ukraine by persons, vehicles and cargo;

6) Information and cyber threats;

7) Threats to the economy of Ukraine, the welfare of its population;

8) Environmental threats.

Even a superficial analysis of certain groups of threats to Ukraine's border security makes it possible to conclude that their counteraction applies to all components (types) of national security, namely: military security, state security, as well as public security and order, etc.

\section{Certain features of the state mechanism functioning concerning Ukrainian border security}

International experience strongly suggests that border security issues resolution in the present context requires international integration. Thus, Anton Grisold defines that a "cooperative" model of international security must take the place of starting point for the formation of a new, more effectively adjusted structure of national and global security in our modern world $^{38}$.

Since 2005, the Organization for Security and Co-operation in Europe (OSCE) has been using the Concept of "Open and Secure Borders in a Free, Democratic and More Integrated OSCE Area without Boundaries". The Concept covers three areas of the OSCE activity like political and military, economic and environmental that prioritize counteraction to threats such as: terrorism; organized crime; trafficking in human beings; arms smuggling and drugs; corruption ${ }^{39}$.

Thus, the reliability of the functioning of the state border security mechanism of Ukraine stems directly from its ability to effectively counter the above groups of threats.

Thus, it is possible to define the basic, generalized functions of the national-level mechanism of ensuring the border security of Ukraine, namely:

implementation of the state policy in the sphere of border security of Ukraine;

\footnotetext{
${ }^{38}$ Grizold A. The concept of national security in the contemporary world.International Journalon World Peace, vol.11, no.3(September1994),pp.37-53Retrieved from:https://www.jstor.org/stable/20751984.

39 Transnational Threats Department Border Security and Management Unit Retrieved from: https://www.osce.org/resources/factsheets/border-security?download=true.
} 
carrying out law-creating activity concerning legal and regulatory framework on border security issues;

collecting information to identify real and potential threats to Ukraine's border security, the causes and prerequisites for their occurrence and possible transformations;

developing and submitting the draft budget expenditures for approval concerning the implementation of border security programs;

carrying out international cooperation in the sphere of border security;

ensuring the adoption and implementation of decisions regarding the elimination of threats to Ukraine's border security, as well as the reasons for their occurrence;

co-ordinating and managing the use of forces and facilities to eliminate threats to border security;

carrying out monitoring (control) over its own activity, implementing the measures of own and internal safety maintenance, other measures on maintenance of own reliability and viability;

performing current analysis of the existing situation, adjusting previously taken decisions, etc.

The content of the generalised functions of the nation-wide border security mechanism of Ukraine implies the availability of certain tools.

Among other tools of influence that can be used to ensure border security, the special place is occupied by the operational and investigative activity, as a system of public and private search, intelligence and counterintelligence activities carried out with the use of operational and operational-technical means ${ }^{40}$.

Operational and investigative activity, as a sphere of law enforcement activity, is regulated by the Law of Ukraine "On Operational and Investigative Activity". Thus, Article 1 of the aforementioned law separately emphasizes that the task of the operational and investigative activity is to search and record actual data on the illegal actions of individuals and groups, the responsibility for which is provided by the Criminal Code of Ukraine, intelligence and subversive activity of special services of foreign states and organizations for the purpose of termination of offenses and in the interests of criminal justice, as well as obtaining information in the interests of the security of citizens, society and the state ${ }^{41}$.

${ }^{40}$ Pro operatyvno-rozshukovu diialnist: Zakon Ukrainy vid 18.02.1992 №2135-Kh II. Data onovlennia : 02.08.18 URL: http://zakon.rada.gov.ua//laws/show/2135-12. (data zvernennia : 23.10.2018).

${ }^{41}$ Pro operatyvno-rozshukovu diialnist: Zakon Ukrainy vid 18.02.1992 №2135-Kh II. Data onovlennia : 02.08.18 URL: http://zakon.rada.gov.ua//laws/show/2135-12. (data zvernennia : 23.10.2018). 
Thus, the national legislator normatively establishes, so to speak, the threefold internal essence of the operational and investigative activity, which is conditioned by the execution of investigative, intelligence as well as counter-intelligence activities.

It is expedient to research the features of practical application of certain functions of the national border security mechanism of Ukraine on the example of the State Border Guard Service of Ukraine, which is an important component of this mechanism and implements the state policy in the sphere of the state border security.

The current stage of the State Border Guard Service of Ukraine development is accompanied by a tendency to deepen the division of spheres and types of activities, complication of organizational and staff structure, which poses additional requirements to the efficiency of coordination of different types of labour activities. This state of affairs creates new requirements for the management system, in particular for the management of the operational and investigative activities of the State Border Guard Service of Ukraine, which necessitates a careful study of the basic conceptual approaches to management.

The State Border Guard Service of Ukraine is the only law enforcement agency of the special purpose, composed of, at the same time, units that carry out intelligence, counterintelligence activities, as well as undertake operational counteraction to crime at the state border of Ukraine. The study of the peculiarities of their functioning within the structure of the State Border Guard Service of Ukraine provides an opportunity, in a way, to extrapolate the experience of the service to the system of border security ensuring as a whole.

Thus, on the basis of studying the capabilities of the available tools in the state mechanism, the measures of border security are carried out through, as well as ensuring the implementation of basic functions by the mechanism, we can conclude that a significant role in this process belongs to operational and investigative activity. Moreover, operational units play a supporting role in the implementation of some of the functions of the mechanism.

These functions include: elaborating draft budgetary expenditures for the implementation of border security programs; ensuring international cooperation in the sphere of border security; ensuring the adoption and implementation of decisions regarding the elimination of threats to Ukraine's border security, as well as the reasons for their occurrence; performing current analysis of the existing situation, adjusting of previously taken decisions, etc.

On the other hand, the units that carry out operational and investigative activity play a major role in the implementation of some of the functions of the border security mechanism. These include: collecting, storing, processing information to identify real and potential threats to Ukraine's 
border security, the causes and preconditions for their occurrence and possible transformations; monitoring of own activity and ensuring reliable functioning of the mechanism within the limits defined by the legislation of Ukraine, as well as ensuring its own and internal security; performing current analysis of the existing situation in order to adjust previously taken decisions, etc.

Thus, the bodies and units that carry out operational and investigative activity are an integral part of the mechanism of ensuring the border security of Ukraine.

\section{CONCLUSION}

Therefore, on the basis of the foregoing, the following conclusions can be drawn: the legislation of Ukraine defines the border security ensuring as one of the most important functions of the state, as well as one of the main tasks of state administration, and priorities in the activity of the state apparatus.

Currently, the mechanism for ensuring the border security of Ukraine is formed and functioning. It includes the armed forces and other security agencies, special services, as well as law enforcement agencies of Ukraine, which perform the tasks of border security, both independently and with the involvement of enterprises and organizations, as well as other legal and natural persons.

The border security mechanism in Ukraine addresses a wide range of functions and tasks in order to identify and counteract national security threats within the border sphere. It researches the reasons and facilitates the elimination of causes of their occurrence.

The State Border Guard Service of Ukraine occupies one of the key places within the state border security mechanism carrying out the direct implementation of the state policy within the sphere of the state border security and protection of Ukraine's sovereign rights in its exclusive (maritime) economic zone.

Based on the experience of the State Border Guard Service of Ukraine, the tasks performed by the operational units in the course of fulfilling the tasks of ensuring border security have been studied and analysed. The role and the place of the units carrying out the operational and investigative activity within the structure of the mechanism of ensuring the border security of Ukraine have been outlined. It has been separately stated that, depending on the nature of the functions, the operational and investigative units may play an auxiliary or a major role.

\section{SUMMARY}

The research is devoted to the study of the issues of functioning of the mechanism of security of the state border of Ukraine. It is stated that state 
border security is an integral component of Ukraine's national security as a state. Particular attention paid to the peculiarities of the operation of the operative-search component of the state mechanism of ensuring the border security of Ukraine. The study is based on the example of the State Border Guard Service of Ukraine, which is the only law enforcement agency in the country. It also includes units that carry out intelligence, counterintelligence activities, as well as operational counteraction to crime at the state border of Ukraine. The peculiarities of their functioning in the structure of the State Border Guard Service of Ukraine make it possible to extrapolate the experience on the service to the system of ensuring the border security as a whole. It also shows the role and place of the units that carry out search operations in the implementation of the border security mechanism functions.

In the course of the research, it was established that the units that carry out search operations in the implementation of certain border security functions, such as collection, storage, information processing, etc., play a major role.

\section{REFERENCES}

1. Konstytutsiia Ukrainy: Zakon Ukrainy vid 28.06.1996 № 254k/96-VR. Data onovlennia: 30.09.2016. URL: http://zakon3.rada.gov.ua/laws/main/ 254k/96-vr. (data zvernennia 23.05.2019 roku).

2. Sytnyk G. P. (2012) Derzhavne upravlinnja u sferi nacionaljnoji bezpeky (konceptualjni ta orghanizacijno-pravovi zasady) [Public administration in the field of national security (conceptual and organizational and legal bases)]. Kyiv : NADU. (in Ukrainian).

3. Tsevelov O. Ye., Zhuk S. M. (2017) Aktualni pytannia zabezpechennia prykordonnoi bezpeky Ukrainy u systemi natsionalnoi bezpeky [Topical issues of ensuring the border security of Ukraine in the national security system].Investments: practice and experience, no10,pp.88-90. (in Ukrainian).

4. Melnyk A.F., Obolenskyi Yu.A., Vasyna A.Yu. (2014) Derzhavne upravlinnia [Governance] / A.F. Melnyk (ed). Kyiv : Znannia. (in Ukrainian).

5. Lytvyn M. M. (2012) Intehrovane upravlinnia kordonamy [Integrated border management]. Khmelnytsky : NADPSU. (in Ukrainian).

6. Kuprijenko D. A. (2014) Osnovni ponjattja ta kateghoriji u sferi zabezpechennja prykordonnoji bezpeky [Basic concepts and categories in the field of border security].Collection of scientific papers of the National Academy of the State Border Guard Service of Ukraine. Series: Military and Technical Sciences, no. 1(64), pp. 357-368.(in Ukrainian). 
7. Slovnyk ukrajinsjkoji movy: Akademichnyj tlumachnyj slovnyk ukrajinsjkoji movy [Dictionary of the Ukrainian Language: Academic Interpretative Dictionary of the Ukrainian Language].Retrieved from:https://sim.in.ua.mekanizm (accessed21 May 2019). (in Ukrainian).

8. Marchenko M.N. (2014). Teoriya gosudarstva i prava[Theory of government and rights]/ V. K. Babaeva (ed.). Moskva : Yurayt. (in Russian).

9. Prytula A.M. (2019) Taktyko-pravovi zasady operatyvno-sluzhbovoi diialnosti Derzhavnoi prykordonnoi sluzhby Ukrainy : monohrafiia [Tactical and legal principles of the operational service of the State border service of Ukraine : monograph]. Odesa : Feniks. (in Ukrainian).

10. Pro natsionalnu bezpeku Ukrainy: Zakon Ukrainy vid 21.06.2018 Vidomosti Verkhovnoi Rady (VVR), 2018, № 31, st.241 URL: https://zakon.rada.gov.ua/laws/show/2469-19 (data zvernennia 18.06.2019 roku)

11. Novyi tlumachnyi slovnyk ukrainskoi movy u trokh tomakh (2008) [A new interpretative dictionary of the Ukrainian language in three volumes]. Kyiv: Akonit.Vol. 1. P. 202. (in Ukrainian).

12. Pro Natsionalnu politsiiu Ukrainy: Zakon Ukrainy vid 02.07.2015 № 580-VIII. Data onovlennia: 06.02.2018. URL: http://zakon5.rada.gov.ua/ laws/show/580-19. (data zvernennia 10.02.2019 roku)

13. Panova O.O. (2017) Informatsiine zabezpechennia publichnoi bezpeky v Ukraini [Public security information in Ukraine]. Actual problems of domestic jurisprudence, vol. 2, no.6,p.126.

14. Abroskyn V.V. (2019) Administratyvno-pravovi zasady zabezpechennia Natsionalnoiu politsiieiu Ukrainy publichnoi bezpeky $\mathrm{v}$ umovakh antyterorystychnoi operatsii : monohrafiia [Administrative and legal principles of ensuring public security in the conditions of anti-terrorist operation by the national police of ukraine: monograph]. Kharkiv: Folio. (in Ukrainian).

15. Novyi tlumachnyi slovnyk ukrainskoi movy u trokh tomakh (2008) [A new interpretative dictionary of the Ukrainian language in three volumes]. Kyiv : Akonit.Vol. 3.P.489. (in Ukrainian).

16. Conceptual frame work for development of the National security system of Ukraine(2015) Analytical report the National Institute for Strategic Studies.KyivRetrieved from:http://en.niss.gov.ua/public/File/docs/ national_security_final.pdf.

17. Vlasiuk O. S. (2016) Natsionalna bezpeka Ukrainy: evoliutsiia problem vnutrishnoi polityky [National security of Ukraine: the evolution of domestic policy issues]. Kyiv : NISD. (in Ukrainian).

18. Shchokin H. V., Holovatyi M. F., Antoniuk O. V., Sladkevych V. P. (ed.)(2007) Menedzhment [Management]. Kyiv : MAUP. (in Ukrainian).

19. Lytvyn M.M. Aktualni pytannia zabezpechennia prykordonnoi bezpeky Ukrainy v suchasnykh umovakh derzhavotvorennia [Topical issues 
of ensuring the border security of Ukraine in modern conditions of state formation] Retrieved from:https://dpsu.gov.ua , upload , file , golova_11(accessed 10 Octover 2019). (in Ukrainian).

20. Horbulin V.P., Kachynskyi A.B. (2009) Zasady natsionalnoi bezpeky Ukrainy[National security principles of Ukraine]. Kyiv : Intertekhnolohiia.P. 136. (in Ukrainian).

21. Babii Yu. (2016) Udoskonalennia dekompozytsii zahroz i nebezpek natsionalnii bezpetsi derzhavy u prykordonnii sferi [Improvement of decomposition of threats and dangers to the national security of the state in the border area]. Proceedings of the National Academy of State Border Guard Service of Ukraine. Series: military and technical sciences, no. 4, pp. 185-196. Khmelnytskyi. (in Ukrainian).

22.Transparency\&Oversight/Brenan Center for Justiceat NYU low.Retrieved from: https://www.brennancenter.org/issues/protect-libertysecurity/transparency-oversight BB.

23. Grizold A. The concept of national security in the contemporary world.International Journalon World Peace, vol.11, no.3(September1994),pp.37-53Retrieved from:https://www.jstor.org/stable/20751984.

24.Transnational Threats Department Border Security and Management Unit Retrieved from: https://www.osce.org/resources/factsheets/bordersecurity?download=true.

25. Pro operatyvno-rozshukovu diialnist: Zakon Ukrainy vid 18.02.1992 № 2135-Kh II. Data onovlennia : 02.08.18 URL: http://zakon.rada.gov.ua//laws/show/2135-12. (data zvernennia : 23.10.2018).

\section{Information about the author:} Pavlo Volynets, Candidate of Psychological Sciences, Associate Professor of Operational and Investigative Activity Management Department Bohdan Khmelnytskyi National Academy of the State Border ty Guard Service of Ukraine, 46, Shevchenka, Khmelnytskyi, Ukraine ORCID ID: orcid.org/0000-0003-0298-2346 